\title{
BOEKBESPREKINGS/BOOK REVIEWS
}

\author{
Kol (dr) Jan Ploeger*
}

\author{
Kmdt C.J. Nöthling (red), Ultima Ratio \\ Regum (The last argument of kings) \\ (Artilleriegeskiedenis van Suid-Afrika) \\ (Artillery History of South Africa) Militêre \\ Informasieburo, SAW/Military Information \\ Bureau, SADF, Publikasie no 8/Publication \\ no 8, Pretoria, 1987, pp 432 met \\ afbeeldings.
}

Op velerlei wyses is verlede jaar aandag aan die 75 ste bestaansjaar van die Suid-Afrikaanse Weermag gewy. Binne die bestek van hierdie bespreking mag daar sekerlik in die verband na die inhoud van Militaria $(1987,17 / 2)$ verwys word. Onder die omvattende titel History of the South African Defence Force 1912-1987/ Kroniek van die Suid-Afrikaanse Weermag 1912-1987, is die belangstellende leser 'n oorsig in voëlvlug van die vroeëre Unieverdedigingsmag en die huidige Suid-Afrikaanse Weermag voorgelê.

Elkeen wat hierdie geskiedenis met sy hoogteen laagtepunte, sy tydperke van vrede en oorlog, van uitbreiding en inkrimping ken, sal onder die indruk kom van 'n indrukwekkende vooruitgang en 'n toenemende militêre slaankrag wat, soos die voormalige Hoof van die Suid-Afrikaanse Weermag, genl C. Viljoen, dit so duidelik gestel het, in diens staan van ons eie voortbestaan en die vrye wêreld. Dit is een van die uitstaande kenmerke van die SAW en sy voorganger die UVM.

En met sy blik op die toekoms gerig het die huidige Hoof van die Suid-Afrikaanse Weermag, genl J.J. Geldenhuys, die noodsaak beklemtoon om die krygsgeskiedenis te ontleed met die oog op die uitken van tekortkominge sowel as suksesse. Dan kan, wat die toekoms betref, die mees gewenste resultate tov die toekomstige bloei van die Suid-Afrikaanse Weermag en die suksesvolle aanwending van ons militêre organisasie en sy slaankrag, verwag word. Dit is slegs 'n gedeelte van die aanloop tot die inhoud van 'n omvattende publikasie, waarin die ontwikkelingsgang van die artillerie, na sy vestiging aan die suidpunt van ons land, in woord en beeld weergegee is. In die woorde van die It-genl F.E.C. van den Berg is die inhoud van die huidige eendragtige spanpoging 'n roemryke geskrif wat meer as drie eeue omspan. En terself- dertyd het dieselfde generaal die geslagte van vandag en môre 'n belangrike taak gegee, tw om te verseker dat die artillerie-verhaal van die toekoms ook 'n roemryke geskrif sal vorm.

Oorgaande na die inhoud van hierdie eerste omvattende artilleriegeskiedenis van ons land van 1652 tot onlangs, moet die volgende belangrike punte beklemtoon word: (a) Die feit dat 'n groot aantal medewerkers daarin geslaag het om van die 21 hoofstukke ' $n$ hegte eenheid te vorm. Die onderdele van hierdie eenheid is logies afgebaken en niks is in die verband oor die hoof gesien nie. (b) Die onderskeie skrywersmedewerkers het, behalwe van sekondêre bronne ook - waar dit moontlik was - met vrug en welslae in die slegs hier en daar ontgonne skatte van die SAW-argief gedelf. (c) Hulle het daarin geslaag om ' $n$ verstaanbare oorsig van 'n uiters belangrike onderwerp aan leke en vakkundiges voor te lê. (d) Daar is met vakkennis en insig gesorg om die teks op ' $n$ aanvullende wyse doeltreffend deur middel van passende illustrasies toe te lig.

Die omvangryke inhoud van die werk laat 'n sketsmatige volledige behandeling nie toe nie. Die leser word dus gevra om met die volgende op- en aanmerkings tevrede te wees. In die tyd van die VOC is kanonne op bastions en op ander strategiese posisies naby die Kaapse kasteel opgestel. Forte, batterye, linies en skanse het verrys om 'n landing van vyandelike magte te betwis en om diefstalle vanuit die binneland te belet. Artillerie het deel van die kolonie se seinstelsel gevorm, die artillerie is georganiseer en die beroepsopleiding is in die 18 de eeu ter hand geneem, terwyl die binnelandse verdediging aan die kommando-organisasie toevertrou is.

Tydens die Britse opmars 1795 is tevergeefs pogings deur artilleriste aangewend om teenstand te bied. Die nuwe heersers het die bestaande kusverdediging opgeknap en 'n eie koIoniale artillerie-organisasie in die lewe geroep. In verband met die binnelandse beveiliging het die artillerie, weens gebrek aan teikens, 'n ondergeskikte rol gespeel. Ten spyte van die omstandigheid het, vanaf 1857, op Britse lees geskoeide vrywilliger-artillerie eenhede ontstaan. 
In Natal het, tydens die Britse koloniale bewind, 'n soortgelyke organisatoriese ontwikkeling plaasgevind. Onder meer het verskeie eenhede oor artillerie-seksies beskik.

In die binneland het, na die Voortrekkertydperk en die stigting van die Boererepublieke die artillerie-ontwikkeling op ' $n$ beskeie wyse in die Oranje-Vrystaat en die Zuid-Afrikaansche Republiek begin om, na die worsteling van 1880-1881 onder kapt R.F.W. Albrecht en It-kol H.P.N. Pretorius tot vroeër ongekende hoogtes uit te styg. Die Jameson-inval was nog 'n stimulant en tydens die Tweede Vryheidsoorlog het die twee korpse hulle regmatige plekke in die militêre organiasasie van die twee Boererepublieke ingeneem.

Hoofstuk 5 (pp 67-88), tw oor die artillerie tydens die Tweede Vryheidsoorlog (1800) munt, soos die ander, uit deur die kritiese wyse waarop die onderwerp, met betrekking tot Britse- en Boeregeskut, die uiteenlopende artillerietradisies en die verskillende taktiese aanwending van die vuurmonde edm, behandel is. Britse en koloniale veldartillerie het teenoor die beste Europese artilleriestukke te staan gekom. Die Boere het, in teenstelling met hulle teenstaanders, die kanonne ooreenkomstig hulle eie militêre tradisie aangewend en suksesse by Modderspruit, Colenso, Spioenkop, aan die Tugela en by Magersfontein behaal, maar nie daarin geslaag om Ladysmith en Kimberley tot oorgawe te dwing nie. Die slag by Berg-en-Dal was nog ' $n$ hoogtepunt aan die kant van die Boereartilleris wat nie soos sy Britse eweknie - aan die handboek verknog was nie. Die Britse artilleriste het in 'n meerdere mate van dissipline geglo en opleiding as 'n noodsaaklikheid beskou.

Tereg verklaar die skrywers van hierdie hoofstuk dat die beste elemente van die Britse- en die Boerestelsels en die wedersydse militêre tradisies in die Univerdedigingsmag (1912) verenig sou word en tot 'n suiwer Suid-Afrikaanse militêre tradisie sou saamsmelt.

Twee jaar na die totstandkoming van die Unieverdedigingsmag (UVM) het die Eerste Wêreldoorlog uitgebreek en het die Suid-Afrikaners agtereenvolgens aan die veldtogte in Duits-Suidwes-Afrika, Duits-Oos-Afrika, die Midde-Ooste en aan die Europese wesfront deelgeneem. In hoofstukke 6-8 is die aandeel van die Suid-Afrikaanse Artillerie, as 'n onderdeel van die Univerdedigingsmag, in die stryd geskets en het die skrywers van die gedeelte daarin geslaag om die artillerie se aandeel te midde van die optrede van die onderskeie magte duidelik te laat uitkom.

In Duits-Suidwes-Afrika het dié soort van oorlog, tw 'n bewegingsoorlog, wat gevoer is, die artillerie nie gepas nie. Waar artillerie in gevegte gebruik is, het die geskutbedieners en ander betrokkenes hulle uitstekend van hulle taak gekwyt. In Duits-Oos-Afrika was, aldus brig-genl J.J. Collyer, swaar, moeilik vervoerbare vuurmonde nie alleen ongeskik nie, maar ook onnodig en skadelik. In die Midde-Ooste het die SAFA se $A$ en $B$ batterye sewe gevegsonderskeidings verwerf.

Behalwe dat die skrywers van hierdie gedeelte onder meer die bekende werk van F.B. Adler geraadpleeg het, is F.J. Stemmet se Geskiedenis van die Suid-Afrikaanse Artillerie 1912-1918 met vrug gebruik.

Die laaste opmerking geld ook tov die rol wat die Suid-Afrikaanse Artillerie aan die wesfront gespeel het (hoofstuk 8). Tydens hierdie stryd het die Suid-Afrikaanse Artillerie verrykende ervaring opgedoen en teen 1918 is, te midde van die krygsgewoel, 'n ongekende mate van prioriteit aan die artillerie toegeken. Deur ' $n$ aantal beslissende uitvindings het die artillerie 'n belangrike wapen geword. Die vergrote vuursnelheid, die toenemende uitwerking van die springprojektiele en die vermeerderde draagkrag van die ladings het die aanvanklike hulpwapen in 'n hoofwapen laat verander.

In hoofstk 9 is die lotgevalle van die artillerie in die Univerdedigingsmag (1912-1939) kortliks geskets. Aanvanklik was die artillerie 'n klein komponent van die UVM, terwyl die latere geldskaarste 'n belemmerende rol gespeel het. Daarna het uiteenlopende vertragings daartoe gelei dat die gestelde doelwitte teen 1939 in heelwat gevalle nog in die papierstadium verkeer het.

In die laasgenoemde jaar was daar 16 batterye waarvan een hoofsaaklik uit lede van die Staande Mag bestaan het.

Die inhoud van hoofstukke $10-12$ is aan die rol gewy wat Suid-Afrikaanse Artillerie tydens die Tweede Wêreldoorlog in Oos-Afrika, Abessinië, Madagaskar, Noord-Afrika en Italië gespeel het. In hoofstuk 12 is hoofsaaklik gebruik van die SAW-Argief gemaak. Ook in hierdie oorlog het, 
aldus prof dr F.J. du Toit Spies, die Suid-Afrikaanse Artillerie met eer uit die stryd getree.

Hoofstukke 13 tot 19 gee die belangstellende leser ' $n$ beeld van die organisasie van die SuidAfrikaanse Artillerie in die na-oorlogse jare.

Vervolgens lig kmdte S.J. du Preez en C.J. Nöthling ' $n$ deel van die sluier van die veldtog van 1975-1976 in Angola, terwyl die laasgenoemde skrywer in hoofstuk 15 'n oorsig van die Suid-Afrikaanse Artillerie-eenhede in die huidige tydvak verstrek. Uit 'n militêr-kritiese oogpunt beskou is die hoofstuk, met die afbeeldings in kleur van die onderskeie kentekens, besonder waardevol.

Dit spreek vanself dat, binne die bestek van die voortreflike publikasie die Kusartillerie (hoofstuk 16) en die lugafweer-artillerie nie vergeet is nie.

Die geskiedenis van die vervaardiging van geskut in ons land tot 1945 is insiggewend. SuidAfrika het, op die gebied 'n groot agterstand ingehaal en het tydens die Tweede Wêreldoorlog grotendeels selfvoorsienend geword. Later het die verskaffing deur oorsese vervaardigers daartoe gelei dat die destydse nywerheidskontrak grotendeels opgedroog het. Die afgelope twee dekades het ' $n$ veranderende wêreldhouding die noodsaaklikheid van eie wapenproduksie op die voorgrond laat tree. Ook ten opsigte van artilleriewapens is ons nywerhede tans nie alleen byna volkome selfvoorsienend nie, maar volgens die bekende militêre joernalis lan $\mathrm{V}$. Hogg in 1984 verklaar het, in verskeie opsigte die res van die wêreld voor met betrekking tot die bewapeningsontwikkeling, aldus maj W.A. Dorning en sers A.C. Lillie in hoofstuk 19 ( $p$ 395). Hulle bespreek onder meer die ontwikkeling van die G-5 155-mm veldkanon, die G-6 selfaangedrewe kanon en die Valkiri 127-mm meervoudige vuurpyllanseerder.

Twee hoofstukke van 'n besondere aard sluit hierdie publikasie af, tw ' $n$ hoofstuk oor artillerietradisie (hoofstuk 20) en 'n huldebetoon aan die artillerieperd (hoofstuk 21).

Ons staan 'n oomblik stil by die nagedagtenis aan die betreurde brig Willem Otto, wat as die geestelike vader van hierdie uitmuntende publikasie beskou kan word. Dan is daar kmdt C.J. Nöthling, mnr J.A. Visser en die skrywers van die hoofstukke (mej L. Jooste, kol J.A. Combrink, maj R. von Moltke, mnr J.A. Visser, prof dr F.J. du Toit Spies, maj W.A. Dorning, kmdt S.J. du
Preez, kmdt C.J. Nöthling, kdr W.M. Bisset, It D. Conradie, sers A.C. Lillie, kol L.A. Crook, maj G.E. Visser en die versorger van aanhangsel $A$, (A Short History of the Gunner's Association), kol R.C. Anderson) wat hul beste kragte aan die onderskeie aspekte van die publikasie gewy het. Deur hulle spanwerk is ons bestaande reeks van militêr-historiese staandaard- en naslaanwerke ongetwyfeld aanmerklik verryk.

Pretoria, Augustus 1987

\section{WESSELS, ANDRÉ: ANGLO-BOER WAR DIARY OF HERBERT GWYNNE HOWELL, HUMAN SCIENCES RESEARCH COUNCIL, PRETORIA 1986, ISBN 0796902879 (218pp, MAP AND ILLUSTRATIONS)}

Since 1972 the Institute for Historical Research (Human Sciences Research Council), has published several diaries and memoirs, inter alia memoirs of General Ben Bouwer as written by P.J. le Riche and edited by O.J.O. Ferreira (1980) and Diary of a National Scout P.J. du Toit 1900-1904, edited by J.P. Brits.

The Anglo-Boer War diary of Herbert Gwynne Howell is the eleventh in this series, but the first written by a British soldier.

Herbert Gwynne Howell was born and bred in Wales, but came to South Africa as a young man and joined the Cape Mounted Riflemen (CMR) one of the finest corps of horsemen of its time. During the Anglo-Boer War (1899-1902) the CMR formed part of the Colonial Division and Gwynne Howell saw action in the North-Eastern Cape and at the siege of Jammersberg Drift near Wepener. He also took part in the first De Wet hunt.

While still a gunner, Gwynne Howell attracted the attention of his superiors and was offered a commission in the Royal Field Artillery (RFA). As a member of the 78th Battery RFA he spent the greater part of the guerilla war in the Western Transvaal, doing garrison and convoy duty or pursuing Boer commandos.

André Wessels, a researcher of the Division for Historical Source Study and Multidisciplinary Research, wrote the introduction and edited and annotated the manuscript.

(The book is available from the Human Sciences Research Council, Private Bag X41, Pretoria 0001). 